\title{
Nowe szczegóły z biografii Aleksandra Mardkowicza (1875-1944)
}

\author{
Mariusz Pawelec \\ Uniwersytet Śląski, Wydział Nauk Społecznych
}

\section{New details concerning the biography of Aleksander Mardkowicz (1875-1944)}

\begin{abstract}
Summary: Aleksander Mardkowicz (1875-1944) was a Karaim publicist, poet and publisher. He was active between the wars in Lutsk, in Volhynia region. The present article presents a number of hitherto unknown details from Mardkowicz's private life as well as his professional career as a notary. They concern, among other things, his sources of income, his financial status and the places where he lived. The article also discusses the contacts that Mardkowicz had with regionalist groups in Volhynia as well as his possible collaboration with Jakub Hoffman (1896-1965) in editing The Bibliography of Wolyn published in 1931-1939 in "The Wolyn Yearbook". The article also includes Polish titles of some his Karaim works, which differing from those commonly known to us, thus enriching out knowledge of Aleksander Mardkowicz's literary achievements. Perhaps the author of these translations was none other than Mardkowicz himself. One hitherto unknown episode in his life was his employment in the city's Homeland Museum during the Soviet occupation of Lutsk in 1940.
\end{abstract}

Keywords: Aleksander Mardkowicz, the Mardkowicz family, biographies, Lutsk, Karaim literary activity, bibliography.

„Dzięki takim ludziom jak Aleksander Mardkowicz zaczęto wydawać książki i pisma karaimskie, krzewić karaimską literaturę, zwłaszcza poezję, słowem: przywracać Karaimszczyźnie to, co przytłumiły czas i rozproszenie, nieustanne 
wędrówki oraz nieubłagane topnienie liczby samych Karaimów” - pisał z uznaniem przed dwudziestu pięciu laty Andrzej Tokarczyk ${ }^{1}$. Obfita spuścizna literacko-wydawnicza jednego z najbardziej aktywnych działaczy na rzecz ożywienia kultury karaimskiej w okresie międzywojennym budzi do dziś uzasadnione zainteresowanie badaczy. Dowodzą tego m.in. publikacje Michała Németha ${ }^{2}$ poświęcone zagadnieniom językowym występującym w listach Karaimów łuckich z XIX i początku XX w., które zostały opracowane i edytowane przez Mardkowicza na łamach „Karaj Awazy”. Także wydanie w ostatnim czasie zbioru listów Ananiasza Zajączkowskiego do Tadeusza Kowalskiego ${ }^{3}$ oraz Aleksandra Mardkowicza ${ }^{4}$ przyniosło szereg interesujących faktów dotyczących literackich dokonań tego ostatniego. Zebrała je i ukazała na szerszym tle biografii karaimskiego wydawcy, publicysty i poety rodem z Łucka Anna Sulimowicz ${ }^{5}$. Natomiast Dovila Troskovaitė ekscerpowała listy Mardkowicza do Hadży Seraji Szapszała ${ }^{6}$. Jest to zaledwie drobny fragment korpusu epistolarnego dotyczącego jego osoby ${ }^{7}$. Wraz ze wcześniejszym omówieniem korespondencji Mardkowicza z prof. Kowalskim, dokonanym przed kilkunastoma laty przez Aleksandra Dubińskiego ${ }^{8}$, stanowi jednak cenny element dla poznania panoramy karaimskiego życia społecznego na ziemiach polskich. Korespondencja ta obejmuje chronologicznie jedynie część okresu międzywojennego. Lata przed rokiem 1927 oraz okres II wojny światowej, sowieckiej i niemieckiej okupacji,

1 A. Tokarczyk, O religii i życiu Karaimów, „Nowe Książki”, nr 11, 1989, s. 33.

2 M. Németh, Errors with and without purpose. A. Mardkowicz's transcription of Euck-Karaim letters in Hebrew script, „Studia Linguistica Universitatis Iagiellonicae Cracoviensis", t. 126, 2009, s. 97-106; tenże, Unknown Lutsk Karaim letters in Hebrew script $\left(10^{\text {th }}-20^{\text {th }}\right.$ centuries). A critical edition, Kraków 2011.

3 Urzeczeni Orientem. Listy Profesora Ananiasza Zajaczkowskiego do Profesora Tadeusza Kowalskiego 1925-1948, red. T. Majda, Warszawa 2013.

4 Listy Ananiasza Zajaczkowskiego do Aleksandra Mardkowicza, red. M. Pawelec, „Almanach Karaimski”, t. 2, 2013, s. 165-187.

5 A. Sulimowicz, Listy do Eucka. Aleksander Mardkowicz jako adresat korespondencji Ananiasza Zajaczkowskiego, „Almanach Karaimski”, t. 2, 2013, s. 37-60.

6 D. Troskovaite, Identity in Transition. The Case of Polish Karaites in the first half of the 20 $0^{\text {th }}$ century, „Codrul Cosminului”, t. 19, 2013, nr 2, s. 210, 214, 222, 225.

7 Mardkowicz prowadził dość bogatą korespondencję z wieloma osobami. Jeden z jego listów dotyczący tematyki karaimskiej z 3 II 1933 r. wzmiankuje etnograf B. Adler, Die Krim-Karäer in geschichtlicher, demographischer und volkskundlicher Beziehung, „Baessler Archiv”, t. 17, 1934, s. 105, przypis 2.

$8 \quad$ A. Dubiński, Fragmenty korespondencji prof. Tadeusza Kowalskiego z Aleksandrem Mardkowiczem, „Przegląd Orientalistyczny”, nr 1 (145), 1988, s. 62-67. 
pozostają w życiorysie Mardkowicza nie w pełni znane. Dotyczy to również pobytu w południowej Rosji przed I wojną światową oraz po wybuchu rewolucji bolszewickiej i w trakcie wojny domowej. Stosunkowo niewiele wiadomo też o jego życiu zawodowym jako notariusza w Łucku.

Szczęśliwie w przeciągu kilku ostatnich lat pojawiło się więcej informacji dotyczących również biografii Mardkowicza i jego rodziny. Wołodymyr Szabarowskij w swej monografii poświęconej skupisku karaimskiemu na Wołyniu przytoczył dane o statusie majątkowym rodziny Mardkowiczów u schyłku XIX stulecia. Według spisu nieruchomości Łucka z 1895 r. Marek Mardkowicz, ojciec Aleksandra, łucczanin w pierwszym pokoleniu, był właścicielem kamiennego domu przy ulicy Karaimskiej wraz z ogrodem o wartości 100 rubli. Dom wyróżniał się wśród drewnianej w większości zabudowy tej części miasta, a cała nieruchomość należała do jednych z najwartościowszych na tzw. Karaimszczyźnie ${ }^{9}$. Prawdopodobnie ten właśnie dom położony w pobliżu kienesy, po drugiej stronie ulicy, miał na myśli Aleksander Mardkowicz w swym opublikowanym drukiem wspomnieniu z dzieciństwa ${ }^{10}$.

Z kolei Dmitrij Prochorow zwrócił uwagę na nieznane wcześniej szczegóły dotyczące małżeństwa A. Mardkowicza. Zawarł je w 1910 r. w Iłży w guberni warszawskiej. Po kilku latach, po urodzeniu pierwszego syna (24 stycznia 1917 r.), Mardkowicz zwrócił się do gminy karaimskiej w Jekaterynosławiu, a następnie do Taurydzkiego i Odeskiego Zarządu Duchowego o uzyskanie kanonicznego statusu swego małżeństwa. Było to konieczne ze względu na jego mieszany wyznaniowo charakter. Pomimo podjętych starań, związek z osobą wyznania innego niż karaimskie nie został uznany za halachiczny ${ }^{11}$.

Kwestia społeczna dotycząca karaimskich małżeństw żywo nurtowała Mardkowicza. Dał temu wyraz publikując pod inicjałami A.M. artykuł pt. Что делать? Из читательских откликов („Караимская жизнь”, nr 7,

\footnotetext{
9 V. Šabarovs'kij, Karaïmi na Volinì. Štrihi do portreta zagadkogo narodu, Luc'k 2013, s. 184.

10 Al.-Mar. [A. Mardkowicz], Sahyncyna „babinecnin”, „Karaj Awazy”, nr 6, 1933, s. 2 (polski przekład A. Sulimowicz, pt. Ku pamięci „babińca”, „Awazymyz”, nr 2 (3), 1999, s. 6).

11 D. Prohorov, Religiozno-pravovye aspekty bračno-semejnyh otnošenij i demografičeskaâ statistika $v$ karaimskih obŝinah Rossijskoj imperii vo vtoroj polovine XIX-načale XX v., [w:] Naučnye trudy po iudaike. Materialy XIX Meždunarodnoj ežegodnoj konferencii po iudaike, t. 3, Moskva 2012, s. 316-317.
} 
1911, s. 82-86 ${ }^{12}$. Była to polemika ze stanowiskiem autora wcześniej zamieszczonego tamże tekstu sygnowanego pseudonimem „Tatły-Dżan”. Na autorstwo tego tekstu wskazała Anna Sulimowicz ${ }^{13}$. Uznać go należy za publicystyczny debiut 36-letniego wówczas Mardkowicza. Dotychczasowa wiedza o jego dorobku literackim została rozszerzona również o wiersz w języku rosyjskim Haбez Гонты. Предание волынских караимов ogłoszony w tym samym moskiewskim czasopiśmie (nr 10-11, 1912, s. 3-4). Utwór oparty na tradycyjnym podaniu karaimskim opowiada o zagładzie gminy w Derażnie w wyniku najazdu kozaków Iwana Gonty w $1766 \mathrm{r}^{14}$. Jednocześnie z zachowanej dokumentacji fotograficznej związanej z postacią Mardkowicza zostało opublikowanych kilka archiwalnych zdjęć przedstawiających jego samego i jego rodzinę, pochodzących z okresu przed- i międzywojennego ${ }^{15}$.

Ustabilizowana pozycja zawodowa pozwalała Mardkowiczowi na finansowanie z własnych zasobów wydawanych w latach 30-tych autorskich broszur oraz redagowanego przez siebie almanachu społeczno-literackiego „Karaj Awazy" ${ }^{16}$. Oprócz zajęć w kancelarii notarialnej Mardkowicz czerpał zyski z najmu nieruchomości. Wraz z miejscowym przedsiębiorcą pochodzenia czeskiego Sebastianem Podowżykiem zakupił w 1928 r. działki budowlane przy ówczesnej ulicy Żeromskiego (dziś Kryłowa) i zabudował je jako nieruchomości komercyjne $^{17}$. Z $1930 \mathrm{r}$. pochodzi istotny dokument rzucający nieco światła na jego ówczesną aktywność społeczną. Jest to umowa zawarta 25 września tegoż roku pomiędzy Stowarzyszeniem Właścicieli Domów miasta Łucka a Związkiem

12 Ibidem, s. 318, por. D. Prohorov, Tavrijs'ke i Odes'ke karaïms'ke duhovne pravlinnâ ta problema mižetničnih ì mižkonfesìnih šlûbìv u serednì XIX - na počatku st. [w:] Odinnadcatye Zaporožskie Evrejskie čtenâ, red. C. Timčenko, F. Turčenko, S. Orlânskij, Zaporože 2007, s. 227-235.

13 A. Sulimovič, Krymskaâ tematika v «Karaj Avazy», „Awazymyz”, nr 4 (21), 2008, s. 9.

14 Współcześnie przedr. „Caraimica”, t. 10, 2009, s. 55. Por. D. Prohorov, Fol'klornye sîžety $i$ motivy na stranicah karaimskih periodičeskih izdanij serediny XIX - načala XX veka, [w:] Ustnoe i knižnoe v slavânskoj i ebrejskoj kul'turoj tradicii, Moskva 2013, s. 154.

15 M. Abkowicz, A. Sulimowicz, Karaj jołlary - karaimskie drogi. Karaimi $w$ dawnej fotografii, [Wrocław] 2010, s. 37, 40, 42.

16 Karaimskaâ narodnaâ ènciklopediâ, t. 5: Kul'tura krymskih karaimov (tûrkov), sost. M.M. Kazas, R.A. Ajvaz, Sankt-Peterburg 2006, s. 75, zawiera mylną informację jakoby wydawnictwo prowadzone przez Mardkowicza działało w Charkowie.

17 W. Piasecki, Jedna z nowych łuckich ulic wokresie międzywojennym, „Monitor Wołyński”, nr 3 (63), 2012, s. 7. Nazwisko zostało zapisane omyłkowo jako „Mordkowicz”, a jego posiadacz miał być nie notariuszem, a adwokatem. 
Zawodowym Dozorców Domowych i Służby Domowej. Wśród trzech przedstawicieli stowarzyszenia, którzy złożyli swoje podpisy pod porozumieniem, widnieje nazwisko Aleksandra Mardkowicza. Umowa dotyczyła szczegółowego ustalenia warunków pracy i płacy dozorców domowych w Łucku, a jej tekst drukiem ogłoszony został w „Wołyńskim Dzienniku Wojewódzkim” w dziale ogłoszeń nieurzędowych ${ }^{18}$. Trzy lata później, w 1933 r. pojawiła się natomiast informacja, że był on właścicielem nieruchomości u zbiegu ulic Karaimskiej i Kruczej o powierzchni ok. 800 m kw. (ogłoszenie Wydziału Hipotecznego Sądu Okręgowego w Łucku z 11 maja 1933 r. $)^{19}$. Do początku lat 30-tych Mardkowiczowie mieszkali przy ul. Jagiellońskiej 111, a następnie pod numerem 95. Przeprowadzka nastąpiła prawdopodobnie w kwietniu 1932 r., jak można sądzić po adresach na zachowanej korespondencji. Ulica Jagiellońska (w późniejszym czasie nosiła nazwę Stalina, a obecnie poetki Łesi Ukrainki) była główną osią komunikacyjną nowej reprezentacyjnej części miasta. Biegnąca na północny-wschód od Starego Miasta ulica Jagiellońska zabudowana była jedno- i dwupiętrowymi stylowymi kamienicami z klinkierowej cegły. Tam też mieściły się urzędy i instytucje społeczno-kulturalne ówczesnego miasta wojewódzkiego, jakim był międzywojenny Łuck. Kancelaria notarialna, w której zatrudniony był Mardkowicz, mieściła się przy ul. Trynitarskiej 1a, na rogu Jagiellońskiej, przy Sądzie Okręgowym zajmującym gmach dawnego klasztoru zakonu trynitarzy.

Innym, mało znanym szczegółem dotyczącym aktywności zawodowej Mardkowicza jest jego artykuł pt. W sprawie zamiany nieruchomości, opublikowany w 1935 r. w fachowym periodyku „Notariat - Hipoteka. Czasopismo poświęcone sprawom ustrojowym i zawodowym notariatu i hipoteki”. Dwutygodnik ten założony i redagowany przez dr. Wiktora Natansona był organem Związku Pracowników Notariatu i Hipoteki RP i ukazywał się w Warszawie w latach 1931-1939. Artykuł Mardkowicza odnotowany został we współczesnym opracowaniu poświęconym dziejom prawa polskiego w okresie międzywojennym $^{20}$. Być może nie był jedynym, a kwerenda zawartości wspomnianego czasopisma, jak i o podobnej tematyce („Przegląd Notarialny” oraz „Kwartalnik

18 Ogłoszenie umowy ustalajacej warunki pracy i płacy dozorców domowych m. Eucka „Wołyński Dziennik Urzędowy”, nr 22, 1930, s. 305-306.

19 Ogłoszenia, „Gazeta Sądowa Warszawska”, nr 21 z 22 V 1933 r., s 336. Także i tam nazwisko zapisane zostało wadliwie jako „Mordkowicz”.

20 S. Płaza, Historia prawa $w$ Polsce na tle porównawczym. Cz. 3: Okres międzywojenny, Kraków 2001, s. 118. 
Prawa Prywatnego"), przyniosła by wiadomości i o innych jego publikacjach o tematyce prawnej.

Omawiając biografię A. Mardkowicza, Anna Sulimowicz zwróciła uwagę na konflikt w środowisku zawodowym, jaki toczył się od maja 1936 do czerwca 1937 r. Trzech łuckich notariuszy wydało przed komisją rozjemczą zwołaną przez Izbę Notarialną w Lublinie negatywną opinię o pracy Mardkowicza. Z kolei on wniósł przeciw nim sprawę z powództwa cywilnego o próbę zniesławienia jego osoby. Ostatecznie orzeczenie sądowe uwolniło go od wszelkich zarzutów, zaś jego adwersarzy uznało winnymi pomówienia. Jak zauważyła wspomniana badaczka jego biografii, „Mardkowicz mógł więc spokojnie wrócić do pracy zawodowej i kontynuować swą działalność wydawniczą"21. O ile to drugie stwierdzenie nie budzi żadnych wątpliwości, zważywszy na publikacje jego autorstwa, które ukazywały się do jesieni 1939 r., pierwsze - pozostaje pod znakiem zapytania. Wątpliwość ta wynika z faktu braku nazwiska Mardkowicza w oficjalnym wykazie notariuszy działających w Rzeczypospolitej Polskiej według stanu na dzień 1 października 1938 r. Widnieją w nim natomiast nazwiska jego wcześniejszych adwersarzy: Andrzeja Hałacińskiego, Apolinarego Jackiewicza i Tadeusza Moszyńskiego, a także kierującego IV Kancelarią notarialną Mieczysława Wysockiego ${ }^{22}$, którego zastępcą w poprzednich latach był Mardkowicz. Niestety, nie wiadomo co było przyczyną braku jego nazwiska. Czy zawiesił tymczasowo pełnienie obowiązków notariusza czy też zrezygnował na stałe z wykonywania tego zawodu przechodząc na emeryturę? Za tym ostatnim rozwiązaniem świadczyłaby nieobecność jego nazwiska wśród łuckich notariuszy także w 1939 r. ${ }^{23}$ Był on osobą dość dobrze sytuowaną materialnie. Dotyczyło to także jego uposażenia emerytalnego. We wrześniu 1936 r. zmieniono zasady dotyczące emerytur notariuszy i pisarzy hipotecznych. Notariusze mianowani przed tym rokiem pobierali uposażenie emerytalne do końca roku, następnie połowę uposażenia, jeśli czysty dochód z prac w kancelarii wyniósł więcej niż 12 tys. złotych rocznie. Jeśli dochód był niższy notariusz pobierał całe uposażenie, którego jednak łączna wysokość wraz z dochodami z kancelarii nie mogła przekroczyć 12 tys. $^{24}$

\footnotetext{
$21 \quad$ A. Sulimowicz, Listy do Eucka, s. 54.

22 Wykaz notariuszów Rzeczypospolitej Polskiej według stanu na dzień 1 października 1938 r., Warszawa [1938], s. 21.

23 Kalendarz informator sadowy na 1939 rok, opr. J. Kirkiczenko, M. Kraczkiewicz, K. Rudzisz, Warszawa 1939.

24 Dziennik Ustaw RP, 1936, nr 74, poz. 526.
} 
W 1934 r. egzamin maturalny zdawał starszy syn, Anatol Mardkowicz. Studia akademickie stały przed nim otworem. Dr Ananiasz Zajączkowski widział go już jako studenta orientalistyki Uniwersytetu Warszawskiego lub Jagiellońskiego $^{25}$. W tym okresie, gdy młodsze pokolenie Mardkowiczów dopiero się usamodzielniało, rodzina potrzebowała niewątpliwie niemałych środków do życia. W 1938 r. maturę zdawał młodszy syn Marek, uczeń I Gimnazjum Państwowego im. Tadeusza Kościuszki w Łucku. Jego postać (utrwaloną także na pamiątkowej fotografii) z okresu wspólnych lat szkolnych przywołuje w swych wspomnieniach wydanych drukiem Marian Feldman. Co ciekawe, w tej samej klasie uczył się również Bogusław Abkowicz, najstarszy syn łuckiego hazzana Rafała Abkowicza ${ }^{26}$. Dodać należy, iż roczne czesne w tej cieszącej się renomą szkole wynosiło znaczącą kwotę 220 zł. Obu karaimskich kolegów szkolnych wspominał także we opublikowanej niedawno autobiografii inny łucczanin, Józef Tarnowski ${ }^{27}$.

Ostatecznie Anatol Mardkowicz nie podjął wbrew wyrażanym oczekiwaniom studiów orientalistycznych. Tym niemniej działalność literacko-wydawnicza jego ojca była znana w środowisku młodych orientalistów czy też szerzej zwolenników idei prometeizmu. Na łamach czasopisma „Orient” wydawanego przez akademickie Orientalistyczne Koło Młodych znalazło się m.in. omówienie zawartości tomu 5 almanachu społeczno-kulturalnego „Karaj Awazy”28. Przypuszczalnie autorem omówienia tekstów opublikowanych po karaimsku był znający ten język Józef Szulimowicz, który rozpoczął w 1933 r. studia orientalistyczne w Warszawie. Był on zaangażowany w działalność OKM i prawdopodobnie jemu należy przypisać zamieszczone na łamach „Orientu” noty omawiające tematykę karaimską. Przykładowo w numerze 3 (19) z 1935 r. ukazała się notka poświęcona publikacji A. Mardkowicza Karaim, jego życie i zwyczaje w przysłowiach ludowych (Łuck 1935). On sam zaś, na co ostatnio zwróciła uwagę

25 List z 8 I 1934 r., zob. Listy Ananiasza Zajączkowskiego do Aleksandra Mardkowicza, nr 61, „Almanach Karaimski”, t. 2, 2013, s. 169 („Kiedyż Pański syn zaciągnie się do szeregów młodych adeptów orientalistyki?”).

26 M. Feldman, Z Warszawy przez Euck, Syberię, znów do Warszawy, Warszawa 2009, s. 26-27. Autor blisko zaprzyjaźniony z Markiem Mardkowiczem, zwanym przez kolegów „Murą”, oddaje jego nazwisko w zniekształconej fonetycznie formie Mortkowicz.

27 J. Tarnowski, R. Raszkowski Ross, Walking with Shadows, Kirkcudbright 2009, s. 16.

28 Z prasy karaimskiej, „Orient. Kwartalnik poświęcony sprawom Wschodu ”, nr 1-2 (9-10) październik 1932 - maj 1933, s. 86. 
A. Sulimowicz ${ }^{29}$, opublikował w grudniu 1933 r. w kwartalniku „Orient” artykuł dotyczący literatury karaimskiej. Można założyć, że został on zamówiony przez redakcję czasopisma. Innym mało znanym tekstem prasowym Mardkowicza, wskazanym przez wspomnianą badaczkę jego dorobku, był artykuł w języku niemieckim Die Karaimen, zamieszczony na stronach wydawanego w Łucku tygodnika "Wolhynischer Bote. Evangelisch-lutherisches Gemeindeblatt für Wolhynien” (nr 21 z 26 V 1929 r., s. 162-163). Pismo to, będące organem niemieckich luteranów, redagowane było przez miejscowego pastora Alfreda Kleindiensta. Siedziba jego parafii znajdowała się przy ówczesnej ul. Karaimskiej 20 (dziś ulica ta nosi ponownie dawną nazwę), niemal po sąsiedzku z kienesą. Mardkowicza musiała zatem łączyć z Kleindienstem dość dobra znajomość, tym bardziej, że ewangelicki duchowny był z urodzenia łucczaninem. Te bliskie relacje potwierdza omówienie broszury Mardkowicza Synowie Zakonu (Łuck 1930) zamieszczone na łamach wydawanego we Wrocławiu kwartalnika "Jahrbücher für Kultur und Geschichte der Slaven“. Autor omówienia, Erdmann Hanisch, streszczając zawartość broszury zaznacza, że egzemplarz nadesłał mu laskawie z Łucka pastor Kleindienst ${ }^{30}$.

Zagadnieniem, które wciąż oczekuje opracowania, są związki łączące Aleksandra Mardkowicza z wołyńskim środowiskiem krajoznawców i regionalistów. Nawet nie docierając do dokumentów archiwalnych, można już teraz pokusić się o zaprezentowanie garści spostrzeżeń. Przeglądając tomy „Rocznika Wołyńskiego", wydawanego w Równem przez Zarząd Okręgu Wołyńskiego Związku Nauczycielstwa Polskiego, napotkać można na liczne wzmianki dotyczące literackich dokonań Mardkowicza. Periodyk publikowany w latach 1930-1939 zamieszczał na swych łamach m.in. Bibliografię Wołynia sporządzaną przez redagującego czasopismo Jakuba Hoffmana. W zestawieniu tym umieszczone zostały publikacje pisane, redagowane i wydawane przez Mardkowicza, a także ich recenzje drukowane na łamach „Myśli Karaimskiej” i „Orientu” ${ }^{1}$. Ponadto bibliografia zawierała wykaz publikacji innych autorów o tematyce związanej z Karaimami Wołynia, takich jak Tadeusz Kowalski, Ananiasz Zajączkowski, Sergiusz Rudkowski czy Abraham Szyszman. Świadczy to o dobrym rozeznaniu

29 A. Sulimowicz, Listy do Eucka, s. 46-47.

30 E. Hanisch, Neue Literatur über das Polnische Wolhynien, ,Jahrbücher für Kultur und Geschichte der Slaven“, Neue Folge, t. 7, 1931, z. 7, s. 303.

31 J. Hoffman, Bibljografia Wolynia, „Rocznik Wołyński”, t. 2, 1931, s. 497 poz. 6; t. 3 , 1934 , s. $554-555$ poz. 258 , s. 556 poz. 261 , s. $571-572$ poz. 306 , s. 610 poz. $381-382$, s. $617-618$ poz. $404-405$; t. $5-6,1937$, s. 408 poz. 570 a, s. $419-420$ poz. 593, s. $458-459$ poz. $659,661$. 
twórcy bibliografii w publikacjach karaimoznawczych ukazujących się w latach 30-tych, nie tylko w Łucku, ale również w Krakowie i Wilnie. Wczytując się uważnie w treść niektórych not, odnosi się wrażenie, że opracowywała je osoba znająca karaimski lub przynajmniej bazująca na omówieniach sporządzonych przez kogoś znającego ten język. Tak jest przykładowo wobec noweli Mardkowicza Birtihi kekłernin (Jomahy askan zamanłarnyn) wydanej w Łucku w $1931 \mathrm{r}$. Krótkie streszczenie jej treści zawiera informację, że fabuła noweli rozgrywa się przed stu laty ${ }^{32}$. Szczegół ten nie jest dostępny dla czytelnika nie obeznanego z językiem oryginału. Informacji takiej nie zawiera także omówienie utworu dokonane po polsku przez Kowalskiego na łamach „Myśli Karaimskiej”33. Krakowski turkolog przetłumaczył tytuł tej publikacji jako Ziarno niebios. Opowieść $z$ minionych czasów i w takiej postaci została utrwalona w polskiej literaturze przedmiotu ${ }^{34}$. Tymczasem w bibliografii opracowanej przez Hoffmana widnieje ona pod tytułem Niebiańskie ziarna. Podanie $z$ minionych czasów $w^{35}$. Zdaje się to potwierdzać przypuszczenie, że autorem wspomnianego omówienia zamieszczonego w „Roczniku Wołyńskim” był sam Mardkowicz ${ }^{36}$. Jego osobistą znajomość z Hoffmanem potwierdza m.in. korespondencja Zajączkowskiego, który również podjął współpracę z redakcją „Rocznika”.

Innym ośrodkiem badań regionoznawczych, oprócz Pracowni Regionalnej Zarządu Okręgu Wołyńskiego ZNP w Równem, stało się środowisko skupione w Polskim Towarzystwie Krajoznawczym. Powołało ono do życia Muzeum Wołyńskie w Łucku oraz organ prasowy - miesięcznik „Ziemia Wołyńska”. $\mathrm{Na}$ jego łamach sekretarz redakcji Jadwiga Nieciowa zamieściła notkę poświęconą

32 Ibidem, t. 3, s. 610 poz. 382.

33 T. Kowalski, Karaimskie wydawnictwa A. Mardkowicza, „Myśl Karaimska”, t. 10, 1932-1934, z. 10, s. 111-112.

34 Zob. W. Zajączkowski, Mardkowicz Aleksander, [w:] Polski słownik biograficzny, t. 19, Kraków [et al.] 1974, s. 617; A. Sulimowicz, Aleksander Mardkowicz-działacz społeczny, pisarz i wydawca, „Awazymyz”, nr 2 (3), 1999, s. 3-4.

35 Co ciekawe, odnotowując recenzję noweli Mardkowicza autorstwa T. Kowalskiego, Bibljografia Wołynia („Rocznik Wołyński”, t. 5-6, s. 408 poz. 570a) podała przekład tytułu w wersji zaproponowanej przez Kowalskiego.

36 Gruntowną znajomość języka karaimskiego u współautora bibliografii poświadcza fragment omówienia noweli historycznej S. Rudkowskiego Krwawe echo Humania na Wołyniu. (Rzeż Kotowska 1768 r.): „Sądząc z języka i stylu opowiadania mogę wnosić, że podanie to było już spisane w języku karaimskim”, zob. J. Hoffman, Bibljografia Wołynia, „Rocznik Wołyński”, t. 3, s. 618. 
poetyckiemu tomikowi Janhy jirłar, wydanemu przez Mardkowicza w 1937 r. ${ }^{37}$ Autorka określiła go jako ,jednego z najpłodniejszych pisarzy i wydawców karaimskich”, wyrażając jednocześnie żal, że jego działalność literacka „pozostaje stosunkowo mało znana szerokiemu ogółowi”. Treść notatki zdaje się świadczyć jednak o jej znajomości poetyckiego dorobku Mardkowicza. Zamieszcza np. polskie przekłady tytułów jego karaimskich poematów Kizdehi bahda - W jesiennym ogrodzie czy Jomak - Baśń. Różnią się one od tych, którymi posłużył się w swej recenzji Kowalski (Jesienia $w$ ogrodzie, Bajka) ${ }^{38}$. Prawdopodobnie były to zatem autorskie przekłady tytułów ${ }^{39}$. Można też założyć, że nie były to tłumaczenia, lecz tytuły polskich wersji sporządzonych przez Mardkowicza. Choć nie zachowały się do dziś rękopisy obu wersji językowych jego utworów wiadomo z innych źródeł, że np. nowela Aziz tas istniała w dwóch autorskich wersjach ${ }^{40}$.

Mało znanym epizodem w biografii Mardkowicza pozostaje jego praca w Muzeum Krajoznawczym (dawniej Wołyńskim) w Łucku. Miało do niej dojść późną wiosną 1940 r., w okresie tzw. „pierwszych sowietów”. Jak podaje w swych wspomnieniach Anatolij Dubleński, historyk sztuki, nauczyciel w gimnazjum, a dodatkowo zastępca dyrektora łuckiego muzeum, Mardkowicz objął wówczas funkcję młodszego pracownika naukowego ${ }^{41}$. Niestety nie są znane inne szczegóły jego działalności w tej instytucji. Prawdopodobnie powierzono mu opiekę nad działem etnograficznym muzeum. Ostatnie lata życia pozostają całkowicie nieznane. Według lakonicznej relacji córki, rodzina Mardkowiczów przeżyła okres wojny i okupacji częściowo w Łucku, a częściowo na wołyńskiej wsi w nadzwyczaj trudnych warunkach ${ }^{42}$. Potwierdzają to drobne wzmianki w korespondencji Ananiasza Zajączkowskiego do Tadeusza Kowalskiego ${ }^{43}$.

37 J. Nieciowa, [rec.] A. Mardkowicz-Kokizow, Janhy Jirłar, „Ziemia Wołyńska”, nr 8-9, 1938, s. 123.

38 T. Kowalski, Nowe utwory poetyckie A. Mardkowicza (Kokizowa), „Myśl Karaimska”, t. 12, 1937-1938, z. 12, s. 123.

39 Tłumaczka twórczości Mardkowicza na język polski, A. Sulimowicz posłużyła się wersjami tytułów W jesiennym ogrodzie oraz Bajka, por. A. Mardkowicz, W jesiennym ogrodzie, [fragm.], „Awazymyz”, nr 4 (37), 2012, s. 3; idem, Bajka, [fragm.], "Awazymyz", nr 1 (30), 2011, s. 3.

40 List z 2 VII 1933 r., zob. Listy Ananiasza Zajaczkowskiego do Aleksandra Mardkowicza, nr 59, „Almanach Karaimski”, t. 2, 2013, s. 166.

${ }_{41}$ S. Kot, O. Ošurkevič, Volins'kij kraêznavčij muzej. Dolâ kul'turnih skarbìv Ukrä̈ni nìd čas Drugoï svitovoï vijni: arhivi, biblioteki, muzeï, t. 1, Kiïv - Bremen 1996, s. 12.

42 A. Sulimowicz, Listy do Eucka, s. 48.

43 Urzeczeni Orientem, s. 127 (list z 30 III 1942 r.), s. 141 (1 III 1944 r.). 
Kontakty osobiste pozostawały wówczas znacznie ograniczone, a istniejąca korespondencja z tych lat uległa zniszczeniu. Mimo podjętych poszukiwań, nie udało się uzupełnić tych skromnych danych żadnymi nowymi szczegółami dotyczącymi biografii Aleksandra Mardkowicza.

Jego życiorys znany w dzisiejszym kształcie wraz z bogatym dorobkiem literacko-wydawniczym świadczy o żywotności wspólnoty karaimskiej i jej kultury w okresie międzywojennym. Wypada przywołać słowa Szymona Firkowicza z roku 1938 poświęcone A. Mardkowiczowi: „O nim można powiedzieć, że w dziejach literatury i języka karaimskiego trwale zapisał swoje imię"44.

\section{Bibliografia:}

Abkowicz, Mariola, Sulimowicz, Anna, Karaj jołłary - karaimskie drogi. Karaimi w dawnej fotografii, [Wrocław] 2010.

Al.-Mar. [Mardkowicz, Aleksander], Sahyncyna „babinecnin”, „Karaj Awazy”, nr 6, 1933, s. 1-10 (polski przekład A. Sulimowicz, pt. Ku pamięci „babińca”, ,Awazymyz”, nr 2 (3), 1999, s. 5-8).

Adler, Bruno, Die Krim-Karäer in geschichtlicher, demographischer und volkskundlicher Beziehung, „Baessler Archiv”, t. 17, 1934, s. 103-133.

Dubiński, Aleksander, Fragmenty korespondencji prof. Tadeusza Kowalskiego z Aleksandrem Mardkowiczem, „Przegląd Orientalistyczny”, nr 1 (145), 1988, s. 62-67.

Feldman, Marian, Z Warszawy przez Łuck, Syberię, znów do Warszawy, Warszawa 2009. Firkowicz, Szymon, O Karaimach $w$ Polsce, Wilno 1938.

Hanisch, Erdmann, Neue Literatur über das Polnische Wolhynien, „Jahrbücher für Kultur und Geschichte der Slaven", Neue Folge, t. 7, 1931, z. 7, s. 285-303.

Hoffman, Jakub, Bibljografia Wołynia, „Rocznik Wołyński”, t. 2-6, 1931-1937.

Kalendarz informator sadowy na 1939 rok, opr. J. Kirkiczenko, M. Kraczkiewicz, K. Rudzisz, Warszawa 1939.

Karaimskaâ narodnaâ ènciklopediâ, t. 5: Kul'tura krymskih karaimov(tûrkov), sost. M.M. Kazas, R.A. Ajvaz, Sankt-Peterburg 2006.

Kowalski, Tadeusz, Karaimskie wydawnictwa A. Mardkowicza, „Myśl Karaimska”, t. 10, 1932-1934, z. 10, s. 108-112.

Kowalski, Tadeusz, Nowe utwory poetyckie A. Mardkowicza (Kokizowa), „Myśl Karaimska”, t. 12, 1937-1938, z. 12, s. 121-126.

Kot, Serhìj, Ošurkevič, Oleksìj, Volins'kij kraêznavčij muzej. Dolâ kul'turnih skarbìv Ukrä̈ni nìd čas Drugoï svìtovoï vìjni: arhìvi, biblìoteki, muzeï, t. 1, Kiïv - Bremen 1996.

Listy Ananiasza Zajaczkowskiego do Aleksandra Mardkowicza, red. M. Pawelec, „Almanach Karaimski”, t. 2, 2013, s. 165-187.

${ }_{44}$ Sz. Firkowicz, O Karaimach $w$ Polsce, Wilno 1938, s. 12. 
Németh, Michał, Errors with and without purpose. A. Mardkowicz's transcription of Łuck-Karaim letters in Hebrew script, „Studia Linguistica Universitatis Iagiellonicae Cracoviensis", t. 126, 2009, s. 97-106.

Németh, Michał, Unknown Lutsk Karaim letters in Hebrew script $\left(19^{\text {th }}-20^{\text {th }}\right.$ centuries). A critical edition, Kraków 2011.

Nieciowa, Jadwiga, [rec.] A. Mardkowicz-Kokizow, Janhy Jirłar, „Ziemia Wołyńska”, nr 8-9, 1938, s. 123.

Ogłoszenia, „Gazeta Sądowa Warszawska”, nr 21 z 22 V 1933 r., s. 334-336.

Ogłoszenie umowy ustalajacej warunki pracy i płacy dozorców domowych m. Eucka, „Wołyński Dziennik Urzędowy”, nr 22, 1930, s. 305-306.

Piasecki, Waldemar, Jedna $z$ nowych łuckich ulic $w$ okresie międzywojennym, „Monitor Wołyński”, nr 3 (63), 2012, s. 6-7.

Płaza, Stanisław, Historia prawa $w$ Polsce na tle porównawczym. Cz. 3: Okres międzywojenny, Kraków 2001.

Prohorov, Dmitrij, Religiozno-pravovye aspekty bračno-semejnyh otnošenij i demografičeskâ̂ statistika v karaimskih obŝinah Rossijskoj imperii vo vtoroj polovine XIX - načale XXv., [w:] Naučnye trudy po iudaike. Materialy XIX Meždunarodnoj ežegodnoj konferencii po iudaike, t. 3, Moskva 2012, s. 306-331.

Prohorov, Dmitrij, Tavrìss'keì Odes'ke karaïms'ke duhovne pravlìnnâ ta problema mìžetničnih ì mižkonfesìnnih šlûbìv u serednì XIX - na počatku st. [w:] Odinnadcatye Zaporožskie Evrejskie čtenâ, red. C. Timčenko, F. Turčenko, S. Orlânskij, Zaporože 2007, s. 227-235.

Prohorov, Dmitrij, Fol'klornye sûžety i motivy na stranicah karaimskih periodičeskih izdanij serediny XIX - načala XX veka, [w:] Ustnoe i knižnoe v slavânskoj i ebrejskoj kul'turoj tradicii, Moskva 2013, s. 141-169.

Sulimowicz, Anna, Aleksander Mardkowicz - działacz społeczny, pisarz i wydawca, „Awazymyz", nr 2 (3), 1999, s. 3-4.

Sulimowicz, Anna, Listy do Eucka. Aleksander Mardkowicz jako adresat korespondencji Ananiasza Zajaczkowskiego, „Almanach Karaimski”, t. 2, 2013, s. 37-60.

Sulimovič, Anna, Krymskâ̂ tematika v «Karaj Avazy», „Awazymyz”, nr 4 (21), 2008, s. 9-12.

Šabarovs'kij, Volodimir, Karaïmi na Volinì. Štrihi do portreta zagadkogo narodu, Luc'k 2013.

Tarnowski, Józef, Raszkowski Ross, Raymond, Walking with Shadows, Kirkcudbright 2009.

Tokarczyk, Andrzej, O religii i życiu Karaimów, „Nowe Książki”, nr 11, 1989, s. 32-33.

Troskovaite, Dovila, Identity in Transition. The Case of Polish Karaites in the first half of the $20^{\text {th }}$ century, „Codrul Cosminului”, t. 19, 2013, nr 2, s. 207-228.

Urzeczeni Orientem. Listy Profesora Ananiasza Zajaczkowskiego do Profesora Tadeusza Kowalskiego 1925-1948, red. T. Majda, Warszawa 2013.

Wykaz notariuszów Rzeczypospolitej Polskiej według stanu na dzień 1 października 1938 r., Warszawa [1938].

Z prasy karaimskiej, „Orient. Kwartalnik poświęcony sprawom Wschodu”, nr 1-2 (9-10) październik 1932 - maj 1933, s. 86.

Zajączkowski, Włodzimierz, Mardkowicz Aleksander, [w:] Polski słownik biograficzny, t. 19, Kraków [et al.] 1974, s. 617. 


\section{Aneks}

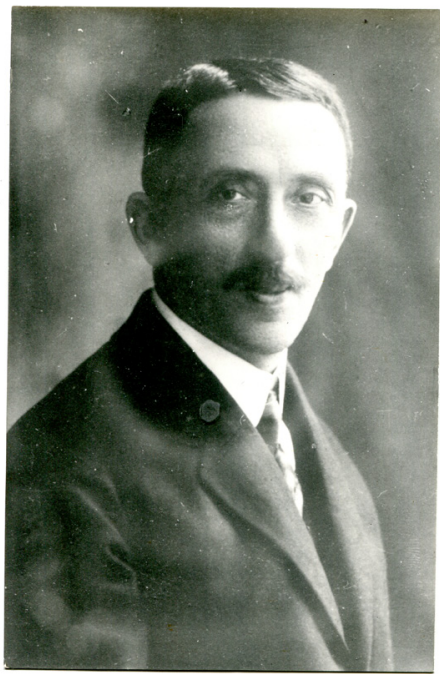

Ryc. I. Aleksander Mardkowicz, lata $20 \mathrm{XX}$ w.

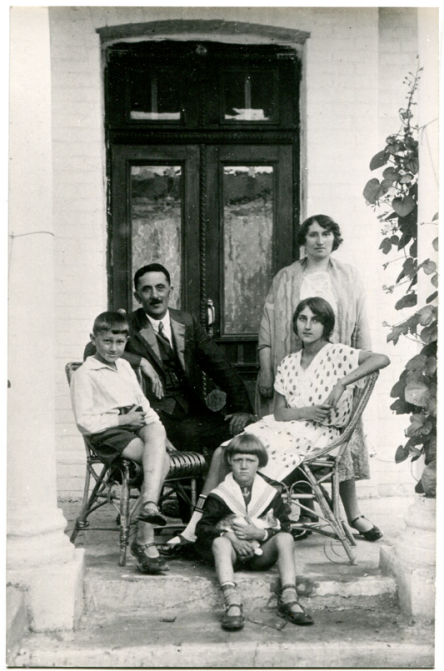

Ryc. 3. Rodzina Mardkowiczów. Łuck, 1926 r.

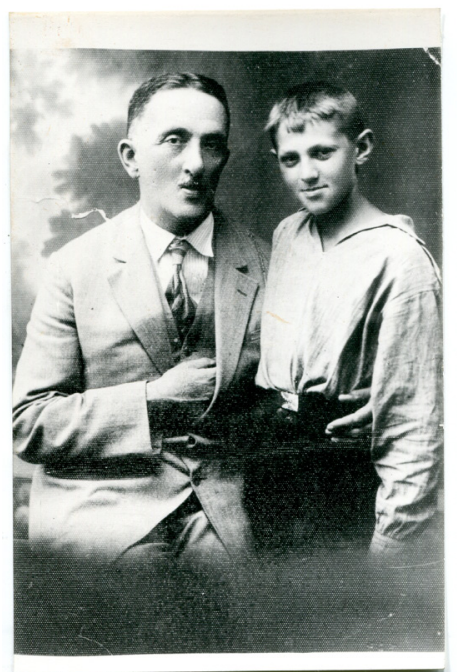

Ryc. 2. Mardkowicz z synem Anatolem.

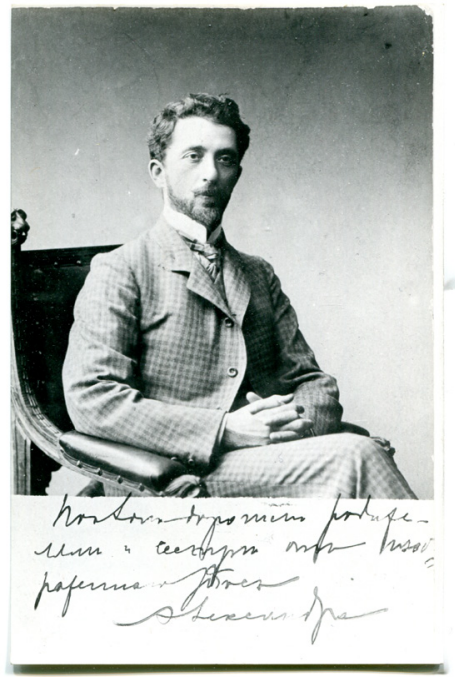

Ryc. 4. Aleksander Mardkowicz. Jekaterynosław, przed $1910 \mathrm{r}$. 


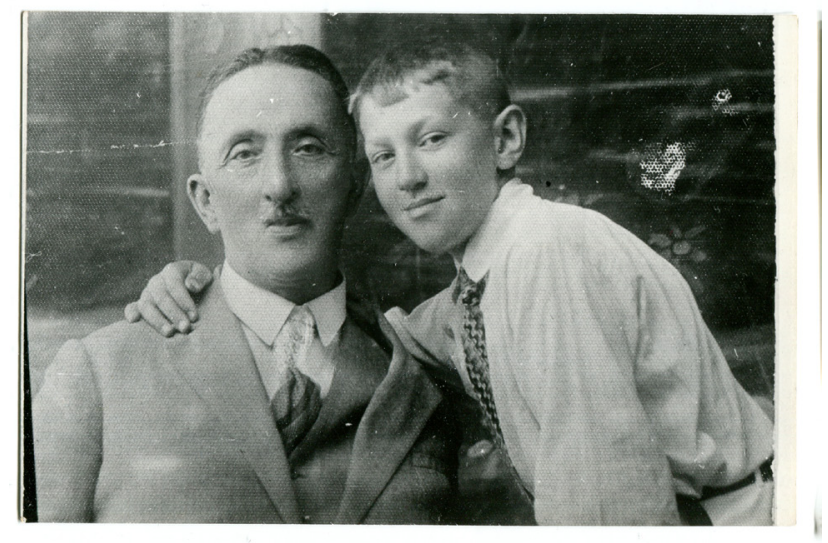

Ryc. 5. Aleksander i Anatol Mardkowicze. 